\author{
Bente Velle Hellang \\ Institutt for nordisk og mediefag \\ Universitetet i Agder \\ E-post: bente.v.hellang@uia.no \\ Gro-Renèe Rambø \\ Institutt for nordisk og mediefag \\ Universitetet i Agder
}

\title{
Teori i praksis og praksis i teori? GLU-studenters refleksjoner om fag og didaktikk
}

\section{Sammendrag}

De siste tiårs forskning, samfunnsdebatt og politikkutforming knyttet til skolesektoren har vært preget av diskusjoner om hva det egentlig innebœrer å vare en kompetent larer, og hvordan de to laringsarenaene $i$ lcrerutdanningene - teoriarenaen og praksisarenaen - best kan utfylle hverandre for å utdanne kompetente larere. I denne artikkelen presenterer vi resultatene fra en undersøkelse blant grunnskolelcererstudenter på én utdanningsinstitusjons grunnskolelcrerutdanning for 1.-7. trinn. I undersøkelsen har vi rettet blikket mot studentenes opplevelser av lcererrollen og av sammenhengen mellom teoriarenaen og praksisarenaen. Dette har vi gjort $i$ tilknytning til ett spesifikt undervisningsfag i lererutdanningen - norskfaget. Gjennom en spørreskjemaundersøkelse og gruppeintervjuer har vi bedt studentene svare på hvordan de mener at norskfaglig kompetanse bidrar til at de kan fylle larerrollen på en god måte, og hvordan de opplever sammenhengen mellom undervisning $i$ norskfaget ved lcrerutdanningsinstitusjonen og praksiserfaringer fra norskfaget i skolen. Målsettingen med artikkelen er å bidra til diskusjonen om hvordan man best mulig kan legge til rette for en god lcererutdanning, hvor studenter og lcererutdannere (på både praksisarenaen og teoriarenaen) opplever gjensidig toleranse og felles forståelse for kompleksiteten som ligger i denne profesjonsutdanningen, og der de anerkjenner de to lcringsarenaenes likeverdighet. Hovedfunnene er at lcererstudentene ikke uten videre klarer å omsette kunnskap mellom de to laringsarenaene, at de $i$ stor grad ser relasjonskompetanse som viktigere enn fagkompetanse, at disse to kompetanseområdene er uavhengige av hverandre og at praksisarenaen er viktigere enn teoriarenaen som grunnlag for å tre inn i lcererrollen.

Nøkkelord: læererutdanning, larerstudent, lærerkompetanse, læererrolle, fagkunnskap, lcringsarenaer, norskfaget 


\begin{abstract}
During the last few decades, research, public debate and policymaking related to the school sector, have been characterized by discussions concerning what being a competent teacher involves. Another issue has been how the two learning arenas in teacher education - the theory arena and the practice arena - can best complement each other to educate competent teachers. In this article we present and discuss results from an investigation conducted among teacher students in teacher education 1-7 at one particular educational institution. We have focused on getting across the students' experiences and understanding of what the teacher role comprises, and how they see the connections between the two learning arenas as campus training and practice training in partner schools in the school subject Norwegian. This is done using a survey and group interviews. Our goal has been to contribute to the ongoing discussion about how to develop a teacher education in which teacher students and teacher educators (in both learning arenas) share an understanding of mutual tolerance and respect. Another has been to develop a common understanding of the complexity of teacher education, and thereby recognizing the equivalence of the students two learning arenas. Our main findings are that the respondents are not automatically able to transfer knowledge between the two arenas. Consider relational competence more important than subject competence, that these two competence areas are seen as independent of each other, and that the practice arena is considered as more important than the theory arena for developing the role of the teacher.
\end{abstract}

Key words: teacher education, student teacher, teacher competence, teacher role, subject knowledge, learning arenas, the subject Norwegian

\title{
Innledning
}

Skoleutvikling er en svært sentral samfunnsoppgave. I den alltid pågående debatten om skoleutvikling er det én ting de fleste er enige om at er sentralt for en god skole: Det er avgjørende viktig å ha kompetente lærere. De siste tiårs forskning, samfunnsdebatt og politikkutforming knyttet til skolesektoren har vært preget av spørsmål knyttet til hva det å være en kompetent lærer egentlig innebærer. Kompetanser som faglig kompetanse, didaktisk kompetanse, pedagogisk kompetanse, metodikkompetanse, relasjonskompetanse, klasseledelseskompetanse osv. har vært drøftet. Alle disse elementene er sentrale for lærerprofesjonen, noe som gjenspeiles i styringsdokumenter for både utdanningene som skal kvalifisere til læreryrket, og for selve utøvelsen av det Når det gjelder lærerutdanningene, drøftes de ulike delkompetansene ofte med utgangspunkt i teori-praksis-dimensjonen: På hvilken måte er ansvaret for de ulike delkompetansene fordelt mellom og ivaretatt på teorifeltet og praksisfeltet? 
Det er viktig å ha innsikt i dette for å kunne si noe om hvordan de to læringsarenaene kan utfylle hverandre på en god og hensiktsmessig måte. Interessen for dette danner utgangspunktet for denne artikkelen, som er knyttet til prosjektet «Helhetlig og bærekraftig grunnskolelærerutdanning [...]» (20132016).

Det er et særtrekk ved profesjonsutdanninger at studentene har to læringsarenaer de skal forholde seg til: den ene er høgskolen eller universitetet de er formelt opptatt som student ved, og den andre arenaen er praksisfeltet. Ingen av disse to arenaene er enhetlige, og de representerer til dels hver sine kunnskapstyper. Lærerutdanningene kjennetegnes ved at studentene på høgskolen eller universitetet møter ulike fag, med ulike særtrekk og faglærere, mens de i praksisperioder møter ulike skolekulturer, elevgrupper og praksislærere. Nilssen \& Klemp (2014) omtaler det å få til et godt samspill mellom disse to kunnskapstypene som en stor utfordring i lærerutdanningene.

Det finnes en temmelig rikholdig forskningslitteratur som drøfter problemstillinger som handler om ulike forhold mellom de mange ulike delkompetansene på disse to læringsarenaene, med et mer generelt utgangspunkt, men en litt mindre rikholdig forskningslitteratur som drøfter forhold mellom ulike delkompetanser med utgangspunkt i spesifikke undervisningsfag i skolen. I denne artikkelen skal vi bevege oss ned fra et overordnet søkelys på pedagogikkens, didaktikkens og skolefagenes kobling til teoriarenaen og praksisarenaen og se nærmere på studentenes opplevelse av ett spesifikt undervisningsfag i lærerutdanningen - norskfaget. Ved å fokusere på kun ett undervisningsfag håper vi å komme nærmere en forståelse av hvorvidt studentene er i stand til å skille mellom fagspesifikk didaktikk og mer generelle didaktiske utfordringer og problemstillinger (allmenndidaktikk).

Vi har valgt å fokusere spesifikt på grunnskolelærerutdanningen for 1.-7. trinn, og har gjennomført en spørreundersøkelse og gruppeintervjuer på én

enkelt lærerutdanningsinstitusjon i ett enkelt studentkull. Målsettingen med undersøkelsen har vært å kunne bidra til diskusjonen om hvordan man best mulig kan legge til rette for en god lærerutdanning hvor studenter og lærerutdannere (på både praksisarenaen og teoriarenaen) opplever at de har en gjensidig toleranse og en felles forståelse for kompleksiteten som ligger i akkurat denne profesjonsutdanningen. Spesielt sentralt er dette akkurat nå, hvor brikkene legges på nytt i forbindelse med overgangen til femårige grunnskolelærerutdanninger. Vårt mål med selve undersøkelsen er todelt:

1) På hvilken måte mener studentene at norskfaglig kompetanse bidrar til at de kan fylle lærerrollen på en god måte?

2) Hvordan opplever studentene sammenhengen mellom undervisning i norskfaget på utdanningsinstitusjonen og praksiserfaringer fra norskfaget i skolen? 
En viktig bakgrunn for søkelyset vi har valgt i denne artikkelen, er gjeldende politiske styringsdokumenter for grunnskolelærerutdanningene, aktuelle stortingsmeldinger og rapporter som handler om lærerrollen, samt tidligere forskning som berører problemstillingene våre. I denne artikkelen ønsker vi å presentere viktige sider ved studentenes opplevelser og refleksjoner slik de fremkommer i spørreskjemaer og intervjuer. Disse resultatene vil så danne utgangspunkt for en diskusjon om hvordan teori-praksis-problematikken på et mer overordnet nivå kan bidra til en forståelse om hvordan en best kan legge til rette for en helhetlig og integrert lærerutdanning.

Politiske styringsdokumenter og tidligere studier om lærerutdanningenes to læringsarenaer og lærerrollen

Teoristudier og praksisopplæring er beskrevet som to ulike, men likeverdige kvalifiseringsarenaer i grunnskolelærerutdanningene i gjeldende plandokumenter, og alle som er involvert i utdanningene, er gitt et ansvar som lærerutdannere (KD 2009, 2010a, 2010b, 2010c) ${ }^{1}$. Det er videre et sentralt krav i grunnskolelærerutdanningene (GLU) at de skal profesjonsrettes (KD 2010a). Samtidig har kravet og forventningene om forskningsbasert undervisning i høyere utdanning blitt tydeligere $\mathrm{i}$ de senere årene (Haug 2010). Både praksisfeltet og teorifeltet er pekt ut og tydeliggjort i rammeverk og planverk, og teoretisk og praktisk kvalifisering skal sammen bidra til å sikre en profesjonskompetanse som lærer (Terum \& Heggen 2010; Nilssen \& Klemp 2014).

Skolen er en utdanningsarena, og læring og læringsperspektiver gjennomsyrer naturlig nok både planverk, skoleforskning og offentlig debatt om skole, noe som understrekes også i Stortingsmelding 11 (KD 2009), som ligger til grunn for det gjeldende rammeplanverket for grunnskolelærerutdanningene 2010-2016 (KD 2010a). Hensikten med denne stortingsmeldingen var fra regjeringens side å legge frem tiltak som skulle bidra til å gjøre skolen og lærerutdanningene bedre. Blant de mest konkrete resultatene av stortingsmeldingen var inndelingen i to likestilte grunnskolelærerutdanninger: grunnskolelærerutdanning for 1.-7. trinn (KD 2010b) og grunnskolelærerutdanning for 5.-10. trinn (KD 2010c). Hensikten med dette var å legge økt vekt på ulike kompetanser direkte rettet mot spesifikke nivåer i grunnskolen. Første kapittel i meldingen heter «Lærer for framtiden», og første underkapittel slår fast at «Regjeringen satser på læreren» (KD 2009). Når stortingsmeldingen skal gjøre greie for hva slags kompetanser som er sentrale for læreren, spesifiseres fire overordnede kompetanseområder som på ulike måter henger sammen og utfyller hverandre: fagkompetanse, didaktisk kompetanse, ledelseskompetanse og relasjonskompetanse (KD 2009). I denne 
artikkelen er det de to første kompetanseområdene som er mest relevante, og da helt konkret lærerens faglige og didaktiske kompetanse i norskfaget.

Om læring i fag slår stortingsmeldingen fast at det fremfor noen er læreren som har ansvaret for elevenes læring:

Det er lærernes oppgave å ivareta målet om mer læring i alle fag, og sørge for at arbeidet med fagene skal gi elevene et best mulig læringsutbytte [...] Lærerens hovedoppgave er å legge til rette for og veilede elevenes læring.

(KD 2009)

I formuleringen i St.meld. nr. 11 vises det også til de da gjeldende bestemmelser i opplæringslova, læreplanverket og andre forskrifter og forskningsresultater når følgende slås fast om sammenhengen mellom lærerens kompetanse og elevenes læring:

Dersom elevene skal få gode faglige resultater, må læreren ha solide kunnskaper i de fagene han eller hun underviser i. Læreren må ha grundig kjennskap til kompetansemålene i læreplanene for fag og kunne velge ut og fordele lærestoff slik at det sikrer god faglig progresjon.

(KD 2009)

Stortingsmeldingen viser til at forskning har vist at det er en slik positiv sammenheng mellom lærerens faglige kompetanse og elevenes læringsutbytte som sitatet over gir uttrykk for, og spesifiserer hvordan solid faglig kompetanse er viktig på flere måter: for den enkelte lærer vil det kunne gi trygghet og stolthet i lærerrollen, i tillegg til at gode fagkunnskaper er nødvendig for at læreren skal kunne differensiere opplæringen på en god måte. For elevene skal dermed lærerens grundige fagkunnskaper bidra til å sikre at han eller hun får så godt læringsutbytte som mulig, ved at læreren er i stand til å vurdere den enkeltes faglige nivå og utvikling i forhold til kompetansemålene for faget. Også på et mer overordnet plan er lærerens faglige kompetanse viktig, idet faglig trygghet åpner for en friere tilnærming til faget og er viktig som grunnlag for improvisasjon når det er nødvendig, slik at undervisningen kan varieres gjennom bruk av ulike arbeidsmåter og et bredt repertoar av læremidler (KD 2009). Faglig kunnskap er et viktig grunnlag for didaktisk virke, og en kan dessuten legge til at faglig kunnskap også kan støtte det relasjonelle: Hvis læreren er faglig trygg, kan det bidra til at han/hun kan og vil ta imot elevenes ulike innspill og bidrag, se deres ulike utgangspunkt, og utnytte disse i den faglige diskursen i klasserommet.

I denne artikkelen kobler vi sammen de to kompetanseområdene faglig kompetanse og didaktisk kompetanse ved å se på hva som skal til for at læreren evner å utnytte fagkunnskap på en hensiktsmessig didaktisk måte i sin konkrete yrkesutøvelse under skiftende forhold, nettopp slik som St.meld. 11 vektlegger. Da blir det avgjørende viktig å se nærmere på hvordan en konkret legger til rette 
for dette i det enkelte undervisningsfag i den enkelte lærerutdanning. For alle lærerutdanningsinstitusjoner ligger for grunnskolelærerutdanningene til grunn for tilbudet som gis til studentene. I gjeldende rammeplan heter det:

Grunnskolelærerutdanningene skal gi kandidatene solide faglige og didaktiske kunnskaper, kvalifisere for forskningsbasert yrkesutøvelse og for kontinuerlig profesjonell utvikling.

(KD 2010a)

Tilsvarende formulering kan gjenfinnes i de vedtatte rammeplanene for grunnskolelærerutdanningene som vil gjelde fra 2017, med understreking av «helhet og sammenheng mellom fag, fagdidaktikk, pedagogikk og praksisstudier og av et nært samspill med profesjonsfeltet og det samfunnet skolen er en del av» (KD 2016a og KD 2016b). I denne sammenhengen er lærerrollen sentral.

I juli 2015 oppnevnte Kunnskapsdepartementet en ekspertgruppe som skulle se nærmere på lærerrollen. I mandatet for ekspertgruppa het det innledningsvis at formålet med nedsettelsen var å frembringe et kunnskapsgrunnlag som kunne gi innsikt i og forståelse av den rollen dagens lærere har i skolen (Dahl et al. 2016). Dette kunnskapsgrunnlaget er så tenkt å være et utgangspunkt for forslag om hvordan en fremtidig lærerrolle og lærerprofesjon og et fremtidig profesjonsfellesskap kan utvikles og styrkes. Gruppa leverte sin rapport i august 2016, og den vil danne et viktig utgangspunkt for utformingen av de nye femårige grunnskolelærerutdanningene som innføres fra og med høsten 2017. I rapporten foreslås sju tiltak som vil forbedre norsk lærerutdanning. Ett av punktene dreier seg om å styrke partnerskapet mellom høyere utdanning og praksisskolene når det gjelder lærerutdanning, altså å styrke forholdet mellom de to læringsarenaene i lærerutdanningene.

Mange studier har vist at lærerstudenter opplever teori og praksis som to atskilte verdener (se f.eks. Solstad 2010, Unneland 2009, Skagen 2010, Kvernbekk 2011, Briseid \& Werner 2013). Like ofte som dette skillet drøftes, pekes det på at det ser ut til at studentene gir praksisfeltet forrang som mer betydningsfylt, mer lærerikt, mer fokusert og mer relevant. Fryktholm (1999) finner at når teori og praksis ikke stemmer overens for studenten, har praksisen forrang. Skagen (2010) drøfter hvorfor det er slik at studenter vurderer praksisopplæringen som mer relevant enn teoriundervisningen, og påpeker at en mulig forklaring på dette kan være at studentenes møte med yrkeslivet er en mer eksistensiell utfordring enn eksamen og vurdering på høyskolen. Kvernbekk (2001) viser til lignende forhold når hun hevder at fordi erfaringene studentene gjør i praksis, er personlige, ofte følelsesmessige, og dessuten er en følge av aktiv deltakelse, blir praksis den vinnende part. Studentene møter det som skal bli deres egen profesjonsvirkelighet (Briseid \& Werner 2013). Når en skal finne en inngang til å forklare hvorfor studenter vurderer praksisopplæringen som mer relevant enn teoriundervisningen, kan det også være sentralt å trekke frem at 
lærerutdanningen krever at studentene trer inn i ulike roller. Nilssen og Klemp har beskrevet praksissituasjoner som situasjoner hvor studenter har to ulike roller som skal balanseres: «rollen som lærere og rollen som lærende» (Nilssen \& Klemp 2014). Her er det rollen som «lærer» som får forrang. Videre har det vært fremhevet at det er læreren som relasjonsbygger og omsorgsgiver som trer frem som gjeldende læreridentitet i norsk skole. Søreide (2010) sammenfatter dette slik:

[...] læreridentiteten blir konstruert og kommer til syne i læreres egne fortellinger om læreryrket og i offentlige dokumenter. Det viser seg å være læreren som elevsentrert, omsorgsfull og inkluderende som dominerer bildet, sammen med en forståelse av læreren som «barnets vokter» og skolen «insider». Slike befestede identiteter kan være viktigere for lærerens prioriteringer enn politisk regulering og faglig kunnskap.

(Søreide 2010)

Longitudinelle studier av norske lærerstudenter tyder på at de vurderer verdien av teoretisk kunnskap lavere på slutten av lærerutdanningen enn i starten (Heggen 2010). Dette indikerer at det altså ikke bare er slik at praksis vurderes som viktigere enn teori i seg selv, men at balanseforholdet mellom disse to arenaene forrykkes ytterligere gjennom studieforløpet istedenfor å utjevnes. Dette er et tankekors, tatt i betraktning hva plan- og rammeverk uttaler om sammenheng og helhet mellom lærerutdanningsarenaene.

\section{Metode}

Det var to ting som sto sentralt da vi skulle velge metode. Det ene var å få en best mulig tilgang til studentenes tanker og meninger om hva som kjennetegner den gode læreren. Det andre var å få vite deres meninger om og opplevelser av forholdet mellom teoristoff som vektlegges i norskstudiet ved lærestedet, og norskfaget slik de møter det i praksisperioder på studiestedets samarbeidsskoler. Vi har i dette prosjektet konsentrert oss om én enkelt lærerutdanningsinstitusjon og ett enkelt lærerstudentkull, og vi har valgt en kvalitativ metodisk tilnærming. Dette valget innebærer at vi ikke uten videre kan generalisere over funnene. Derimot gir valget mulighet for dybdeboring og nyanseringer på et mer detaljert nivå, noe som kan frembringe verdifull innsikt i informantenes resonnementer og vurderinger (Brinkmann og Tanggaard 2010, Thagaard 2013). Det vi ønsker å bidra med, er mer nærgående innsikt i informantenes meninger og erfaringer, som så kan bidra til å fylle ut en del av et større bilde.

Det utvalgte lærerstudentkullet var tilknyttet grunnskolelærerutdanningen for 1.-7. trinn (GLU 1-7). Det er bare i denne grunnskolelærerutdanningen at norsk er et obligatorisk fag. Innenfor grunnskolelærerutdanning for 5.-10. trinn (GLU 5-10) ville vi kun fått tak i den studentgruppa som var spesielt interessert i akkurat norskfaget og derfor hadde valgt dette som undervisningfag. Det er langt 
færre studenter som tar norsk innenfor GLU 5-10 enn innenfor GLU 1-7, så dermed bidro valget av denne utdanningen også i større grad til å sikre informantenes anonymitet. Én av forskerne underviste selv på norskemnet den aktuelle høsten. Forskningsprosjektet var ikke på noe tidspunkt gjort kjent for studentene før den dagen spørreskjemaet ble delt ut, og ingen av spørsmålene verken i spørreskjemaet eller i gruppeintervjuene - berører forhold som direkte har å gjøre med enkeltfaglærernes rolle i undervisning e.l.

Vi valgte å benytte spørreskjema (vedlegg 1) som metode for å fange inn hovedtendenser i den større studentgruppa (hele det valgte kullet), og deretter supplere dette materialet ved å gjennomføre gruppeintervjuer (se intervjuguide, vedlegg 2). Spørreskjemaet var ikke utformet på en slik måte at det er interessant som grunnlag for kvantitative studier, da det utelukkende besto av åpne spørsmål. Vi har også hatt tilgang til semesterplaner, pensumlister o.l. Ved studiestedet har studentene norsk i sitt 2. og 3. semester. Alt materialet ble samlet inn ved slutten av perioden for norskstudiene, det vil si ved slutten av 3 . semester. Totalt var det 59 studenter som hadde eksamensrett i emnet dette semesteret. Det var et poeng for oss at studentene skulle være ferdige med all praksis hvor norsk var fokusfag, slik at de i prinsippet skulle ha mest mulig erfaringer fra forholdet mellom de to utdanningsarenaene.

Høsten 2014 utviklet vi spørreskjemaet, en intervjuguide og et informasjonsskriv som ble sendt inn til Personvernombudet for forskning ved Norsk samfunnsvitenskapelig datatjeneste (NSD). Etter godkjenning ble et informasjonsskriv om prosjektet delt ut til samtlige aktuelle studenter. Dette ble gjort i forbindelse med den siste obligatoriske fellessamlingen det semesteret, for å forsøke å få så god deltakelse som mulig. Studentene fikk anledning til å få svar på ting de lurte på i forbindelse med prosjektet og spørreskjemaet ved at begge forskerne var til stede, og de ble deretter bedt om å underskrive en samtykkeerklæring for å delta som informant. Etter at dette var gjort, fikk studentene spørreskjemaet utdelt. Av de totalt 59 studentene som hadde eksamensrett i det aktuelle norskemnet høsten 2014, var det 51 studenter som besvarte spørreskjemaet og leverte samtykkeerklæring.

I spørreskjemaet tematiseres lærerrollen, samt ulike sider ved forholdet mellom teori og praksis, og flere av spørsmålene var utformet med bakgrunn i kjennskap til hvilke temaer som hadde vært tatt opp i undervisningsøkter i forkant av den siste praksisperioden. Selve spørsmålsformuleringene var utformet på bakgrunn av et pilotprosjekt som vi gjennomførte på et tidligere studentkull. Pilotprosjektet viste at studentene i varierende grad gjenkjente fagterminologi vi hadde benyttet i spørsmålsformuleringene, og i det endelige spørreskjemaet valgte vi derfor å knytte spørsmålene våre mer direkte til formuleringer i planverk som vi kunne gå ut fra at studentene var kjent med. Samtidig håpet vi at formuleringene fra kjente planverk ville bidra til at studentene mer tydelig ville rette oppmerksomheten mot sammenhenger mellom teori og praksis (se vedlegg 1). Praksisperioden var plassert slik dette semesteret 
at det bare var tre undervisningsuker på campus i forkant av praksis. I praksisperioden denne høsten skulle alle studentene ha praksis i 1. eller 2. trinn i grunnskolen. I de tre ukene i forkant av praksisen jobbet studentene med fonologi og grunnleggende lese- og skriveopplæring på utdanningsinstitusjonen. Innenfor dette jobbet de med barns språkutvikling, sammensatte tekster, ABCverk, lettlestbøker og vurdering av lettlestbøker, lesehefter og forhold mellom muntlighet/skriftlighet. Studentene arbeidet også med en praksisoppgave i forbindelse med praksisperioden sin. Temaet for praksisoppgaven var grunnleggende lese- og skriveopplæring, og oppgaven gikk ut på at hver enkelt praksisgruppe skulle lage en presentasjon av hvor elevgruppa befant seg når det gjaldt lese- og skriveferdigheter. Videre skulle de lage et undervisningsopplegg i norsk fra praksisperioden, og dette skulle ha med lese- og skriveopplæring å gjøre. Praksisoppgaveresultatet ble senere presentert for hele studentgruppa i forbindelse med en obligatorisk undervisningsøkt på utdanningsinstitusjonen.

Etter innlevering av spørreskjema og endt praksis med norsk som fokusfag, ba vi studenter (basert på praksisgrupper) om å delta på gruppeintervjuer. Vi ønsket å få tilgang til tre-fire studentgrupper. Fire grupper meldte seg, og vi gjennomførte intervjuer med alle gruppene i november 2014. To av gruppene besto av to studenter, én gruppe besto av tre studenter og én gruppe besto av fire studenter. I gruppeintervjuene ba vi om utdypende refleksjoner i tilknytning til det som ble tatt opp i spørreskjemaene. Vi tok lydopptak av gruppeintervjuene. Våren 2015 ble gruppeintervjuopptakene transkribert av en eksternt tilsatt transkribør, og spørreskjemadataene ble nummerert og systematisert. De to datasettene vi har beskrevet her, danner basis for analysen vår. I analysen har vi tatt utgangspunkt i spørsmålene fra spørreskjemaet (datasett 1). Vi behandler hvert spørsmål for seg, og har så brukt informasjon fra intervjutranskripsjonene (datasett 2) for å belyse funn fra spørreskjemasvarene.

De valgene vi har gjort når det gjelder informantutvalg og metode, har betydning for datamaterialet vi bygger på. Vi har i nokså stor grad latt overordnede styringsdokumenter danne utgangspunkt for spørsmålene studentene fikk. En kan selvsagt tenke seg at en annen måte å operasjonalisere spørsmålene på ville kunne gi andre typer svar. For eksempel kan det være at mer åpent formulerte spørsmål kunne gitt større bredde og variasjon. Videre kan det påpekes at informantene våre har hatt norsk som obligatorisk fag, og en kan tenke seg at svarene vi har fått på spørsmålene våre, ville ha vært annerledes dersom vi isteden hadde valgt informanter fra norsk fordypning, det vil si studenter som selv har valgt å fordype seg i akkurat dette faget. Et slikt informantutvalg ville også ha betydd at dataene ville kommet fra informanter som ikke er i starten av utdanningsløpet sitt. En kan anta at det vil kunne være stor forskjell på refleksjoner og holdninger hos studenter som er tidlig i utdanningsløpet og studenter som nærmer seg fullført utdanningsløp. Det har likevel vært viktig for oss å ha den valgte informantgruppa i fokus. For den valgte informantgruppa er det slik at de får tilkjent undervisningskompetanse i 
norsk for hele barnetrinnet. I et samfunnsperspektiv er det naturligvis svært viktig å få et ordentlig innblikk i hvordan akkurat denne gruppa lærerstudenter opplever den kompetansen de opparbeider seg gjennom teoristudier og praksisopphold knyttet til norskfaget - de skal undervise i det som er undervisningsspråket i så godt som alle fag fra 1. til 7. trinn.

\section{Resultater}

Vi har i det følgende konsentrert oss om hovedlinjer i resultatene fra spørreskjemaer og gruppeintervjuer. Resultatene er strukturert med utgangspunkt $\mathrm{i}$ de to perspektivene som defineres innledningsvis: Hvordan grunnskolelærerstudenter opplever at norskfaglig kompetanse bidrar til at de kan fylle lærerrollen på en god måte, og hvordan de opplever sammenhengen mellom undervisning i norskfaget på campus og praksiserfaringer fra norskfaget i skolen. Det første delkapitlet nedenfor omhandler primært det første av disse perspektivene, mens det andre delkapitlet primært omhandler det andre. Vi presenterer først svar fra spørreskjemaet ${ }^{2}$, og deretter intervjuuttalelser, siden disse er tenkt som supplerende materiale i studien.

\section{Norskfaglig kompetanse og den gode læreren}

Her forsøker vi først å sirkle inn studentenes tanker om norskfagets betydning i skolen (spørsmål III i spørreskjemaet), og deretter ser vi svarene på dette spørsmålet i sammenheng med hva de anser som en lærers viktigste kompetanse, hva som kjennetegner en god lærer (spørsmål VII). Det generelle spørsmålet om norskfagets betydning i skolen er relevant for denne studien, gitt det faktum at norsk er lese- og undervisningsspråk i så godt som alle fag i norsk grunnskole (med delvis unntak for fremmedspråkopplæring). Vi ønsker å få frem studentenes egne holdninger og refleksjoner knyttet til norskfaget i skolen, siden det vil kunne påvirke hvordan de svarer på de ulike spørsmålene i spørreskjemaet og intervjuene.

På spørsmål om hva de tenker om norskfagets betydning i skolen (spørsmål III), svarer samtlige studenter at norskfaget er av stor eller svært stor betydning. «Ekstremt viktig» sier en student. Felles for svært mange av svarene er at de peker på norskfagets redskaps- og nytteaspekt i et fremtidsperspektiv, og så godt som alle kobler det til lese- og skriveopplæring, noe som sånn sett er naturlig i og med at samtlige studenter hadde 3 ukers praksis på småskoletrinnet dette semesteret. Mange studenter peker på den grunnleggende lese- og skriveopplæringen som en nøkkelferdighet til kunnskapstilegnelse også i andre fag: «Uten å kunne lese og skrive er det nesten umulig å tilegne seg kunnskap videre i skolegangen» (sitat 1 ). 
Mange svar peker også ut over elevenes skolegang og konkrete kunnskapstilegnelse i norsk og andre fag, men er fremdeles forankret i lese- og skriveopplæringens betydning: «Det er en grunnstein som må være godt på plass for at vi skal funke i samfunnet», sier en student (sitat 2).

Noen få studenter trekker også frem det de anser som andre betydningsfulle sider ved norskfaget, og legger seg tett opp til det man gjerne omtaler som «dannelsesaspektet» ved faget: «Stor betydning for livet videre - for å delta i en kultur og et samfunn bør man ha noen referanserammer felles» (sitat 3). Oppsummert må det sies å være en felles oppfatning blant studentene at norskfaget er av svært stor betydning i skolen og for elevene.

I spørreskjemaet stilte vi studentene det mer generelle spørsmålet «Hva mener du kan gjøre deg til en god lærer?» (spørsmål VII). Alle studentene har svart på spørsmålet, og to hovedperspektiver går igjen: et elevsentrert perspektiv, med vekt på relasjonelle forhold, og et faglig perspektiv, med vekt på kunnskap. Innenfor begge disse to perspektivene vektlegges faktorer som tilpasset opplæring, variert undervisning og det å kunne benytte ulike metodiske tilnærminger i undervisningssituasjoner.

Om lag 2/3 av informantene fremhever at det viktigste kjennetegnet ved en god lærer er evnen til å se og lytte til den enkelte eleven, og å utvikle gode personlige relasjoner. En student sier for eksempel: «Jeg bryr meg om mennesker, er åpen, føler jeg er en god lytter, og jeg elsker å jobbe med barn» (sitat 4). Svært ofte kobles det relasjonelle sammen med det å være en tydelig leder og/eller å kunne tilpasse undervisningen. «At jeg får en god relasjon med elevene, er tydelig og prøver å være rettferdig. Er autoritær, men har en fin balanse på det» (sitat 5). Det fremstår som viktig for studentene at de går inn i en rolle som voksen omsorgsperson i møte med elevene (som dermed blir gjort til omsorgsmottakere), men det er vanskelig å lese ut fra svarene hva studentene mener skal til for å gjøre læreren til en autoritet og leder i klasserommet. Et par utsagn skiller seg ut ved at de antyder faglig kunnskap som en inngang til gode relasjoner med elevene: «At jeg vil gjøre alt jeg kan for å utfordre de gode/raske elevene, samtidig som jeg vil ha med meg de som sliter» (sitat 6), «At jeg ser elevene på deres nivå, og at jeg kan hjelpe de til neste nivå» (sitat 7). Disse utsagnene knytter den personlige relasjonen til faglig kompetanse på en måte der det ene betinger det andre og ikke kan løses fra hverandre.

Om lag 1/3 av studentene nevner eksplisitt det å ha gode fagkunnskaper som sentralt for å være en god lærer. Også dette faglige perspektivet kobles opp mot det å tilpasse og variere undervisningen. En student sier for eksempel at det som gjør ham/hun til en god lærer, er «God faglig kunnskap, forståelse for hvordan elever lærer, tålmodighet, god klasseleder, forståelsesfull, omtenksom, utforskende og at jeg hele tiden prøver ut nye triks og metoder for å få alle elever med» (sitat 8).

Også i gruppeintervjuene tematiseres lærerens kompetanse, og vi ber studentene om å reflektere rundt sine oppfatninger av den «perfekte» læreren. Vi 
finner den samme grunnleggende todelingen som i uttalelsene fra spørreskjemaet: det relasjonelle og det faglige. I intervjuene ser vi imidlertid at de to ferdighetene settes tydeligere opp mot hverandre, og det relasjonelle gis en klar forrang: «Tror egentlig det er noe av det viktigste, relasjonen du har med elever [...] Og selvfølgelig så må de jo ha kunnskap, men, av det du skal lære, men jeg tror noe av det viktigste er egentlig relasjonen du får til elevene» (sitat 9). I et oppfølgingsspørsmål blir en av de fire studentgruppene spurt direkte om betydningen av fagkunnskap for å være en «perfekt» lærer. Studentene anerkjenner umiddelbart behovet for fagkunnskap, men er raske til å vri perspektivet over mot en mer generell evne til å formidle: «Du skal ha mye kunnskap om de fagene du skal undervise i. Men og det å faktisk kunne formidle den kunnskapen ut til elevene, sånn at de forstår det, å ha den formidlingskompetansen, det er jo kjempeviktig» (sitat 10).

Oppsummert kan vi si at studentene er tydelige i å anerkjenne fagkunnskap som en del av den gode (norsk)lærerens kompetanse, men likevel underordnet den personlige relasjonen med elevene, og også underordnet og skilt fra en mer generell formidlingskompetanse.

\section{Norsklæreren mellom teori og praksis}

Tre av spørsmålene i spørreskjemaet (IV, V og VI) går dypere inn i forholdet mellom teori og praksis i norskfaget på utdanningsinstitusjonen og på praksisskolene, og undersøker mer spesifikt hvordan grunnskolelærerstudentene opplever at utviklingen av norskfaglig kompetanse finner sted i møte mellom de to arenaene.

Vi inkluderte et spørsmål i spørreskjemaet som viste til formuleringen fra rammeplanen om at studiene skal vektlegge helhet og sammenheng mellom teori- og praksisstudier, og spurte studentene: «Dette ansvaret deles mellom praksislærere på praksisskolene og faglærerne på Universitetet i Agder. I hvilken grad opplever du at helheten og sammenhengen i sitatet ovenfor blir ivaretatt i norskfaget i GLU 1-7? (spørsmål VI)». Her gikk svarene i ulike retninger. Mens en del av studentene svarte at de var tilfredse med sammenhengen mellom teori- og praksisopplæringen, mente andre at det var dårlig sammenheng og helhet. Det alle studentene er enige i, er at det er behov for mer opplæring i metodikk. Blant studenter som er fornøyde med sammenhengen, finner vi svar som dette: «Helt ok. Vil gjerne lære mer på studiestedet om hvordan jeg som lærer kan lære bort mest mulig. (Metoder, teknikker osv.)» (sitat 11). Blant studentene som er misfornøyde med sammenhengen mellom teori og praksis, ser vi ofte at det er teoriarenaens betydning som nedvurderes, ved at det påpekes at teoriarenaen i for liten grad er knyttet direkte opp mot det de har erfart som sentralt i praksisperiodene: «Det blir ofte mye teori i pensum, på forelesninger og i seminar. Vi får lite opplæring i gode metoder som vi kan bruke i praksis» (sitat 12). Igjen er det metodikk som 
etterlyses, og det ser ut til at studentene forventer at dette er noe teoriarenaen har et hovedansvar for.

Flere av spørsmålene i spørreskjemaet åpnet i større eller mindre grad for at studentene kunne fokusere på skiller mellom teorifeltet og praksisfeltet. Dette er et skille vi på forhånd regnet med at mange studenter uten videre ville gripe fatt i, også der det ikke var tematisert i spørsmålsformuleringen, noe tidligere forskning på feltet har vist (se f.eks. Briseid \& Werner 2013; Kvernbekk 2011; Unneland 2009; Skagen 2010; Solstad 2010). Siden vi forventet at studentene ville fokusere på skiller mellom de to arenaene, ønsket vi å ha med et par spørsmål som på en konkret måte åpnet for at studentene kunne klare å knytte sammen disse to arenaene. I det siste semesteret disse studentene har obligatorisk norsk, er grunnleggende lese- og skriveopplæring et sentralt emne. Med henvisning til emnebeskrivelsen for norskemnet dette semesteret spurte vi om studentene hadde opplevd at teoretisk kunnskap om den første lese- og skriveopplæringen hadde vært til hjelp i praktiske undervisningssituasjoner (spørsmål V). Vi ba studentene om å knytte svarene opp mot det å forstå elevers ferdigheter og utfordringer (a), og mot hvorvidt de selv på bakgrunn av teoretisk kunnskap mener at de kan gi faglig relevant opplæring (b).

50 studenter har besvart spørsmål V. De aller fleste har svart at de har hatt god nytte av den teoretiske kunnskapen for å kunne forstå elevenes nivå ( $\mathrm{V} \mathrm{a}$ ): «Ja! Når man ser at en elev sitter og staver/lyderer seg frem til et ord, mens eleven ved siden av avkoder og leser setninger uten problem, er det godt å vite at begge ligger innenfor normalen for 6-7 åringer» (sitat 13) og «Teoretisk kunnskap har i stor grad vært til hjelp for å forstå elevenes ferdigheter og utfordringer. Tenker spesielt på det med objektpermanens. Eks.: I innlæringen av bokstaven $S$ var det mange som skrev den motsatt vei» (sitat 14). I svarene på dette spørsmålet ser vi at studentenes svar i stor grad avdekker i hvilken grad de faktisk kjenner pensumlitteraturen og fagstoffet, ved at de tar i bruk spesifikk fagterminologi. Det er også studenter som svarer negativt på spørsmålet, og som mener at de har hatt både for lite faglitteratur og for lite undervisning før praksisperioden: «I noen grad, men kunne godt fått mer undervisning på campus med gode eksempler på hva vi kan gjøre i forskjellige situasjoner» (sitat 15). Andre studenter er mer opptatt av spesialpedagogiske problemstillinger, og savner mer pensum om spesifikke lese- og skrivevansker: «Vi må lære meir om skrive- og lesevanskar, samt tegna vi skal sjå etter! Alt vi har hatt om begynneropplæringa var veldig nyttig å ta med inn i praksis til elevar med normalt utviklingsløp, men problemene oppstod då vi skulle hjelpe dei svakare lesarane/skrivarane» (sitat 16) og “"Vi burde lære mer om forståelsen av de som kanskje henger litt etter. Jeg synes det var litt utfordrende i praksis. (Møtet med elever med lese- og skrivevansker)» (sitat 17).

Vi finner også studenter som leder oppmerksomheten bort fra norskfaget og mot mer generelle allmenndidaktiske problemstillinger som gjelder undervisning på småskoletrinnet: «Kunne INGENTING om hvordan vi skulle 
undervise så små elever. Burde hatt mer undervisning om elevene, og ikke bare teori om alt annet. Vanskelig for oss som er vant med eldre elever å vite hvordan vi skal undervise så små elever» (sitat 18). Også her etterlyser studentene metodisk opplæring, men nå for å løse mer allmenndidaktiske utfordringer.

Fire studenter skiller seg ut ved at de i svaret på Va bruker anledningen til selv å opprette et tydelig skille mellom teori- og praksisfeltet: «Har vært litt til hjelp, men sitter igjen med større læringsutbytte fra praksis» (sitat 19), «I liten grad har det vært til hjelp, men sitter igjen med større utbytte fra praksis. Der ser man i praksis hva elevene sliter med, har som utfordringer» (sitat 20), "Ikke konkret for min del. Jeg mener og tror at praksis er den arenaen der vi som studenter lærer mest og tar inn mye informasjon gjennom observasjon. Slik er det for meg» (sitat 21), «Det har vært greit med det teoretiske, men en kunne vært forberedt mer på hva vi ville møte i praksis» (sitat 22). Istedenfor å se sammenhenger, viser disse studentene at de opplever de to læringsarenaene som klart atskilte.

Det som er interessant, er at studentenes svar på hvorvidt de selv kan gi faglig relevant opplæring (spørsmål V b) ikke følger direkte av hvorvidt de mener at de er i stand til å forstå elevers ferdigheter og utfordringer $(\mathrm{V}$ a). Mens tre fjerdedeler av studentene oppgir at teoretisk kunnskap har gjort dem i stand til å forstå elevers ferdigheter og utfordringer, svarer bare halvparten at de selv er i stand til å gi relevant faglig opplæring, og halvparten av disse igjen (totalt en fjerdedel av studentene) mener at de bare delvis er i stand til dette.

I et annet spørsmål (IV) presenterer vi studentene for et av ferdighetsmålene i norskkursets emnebeskrivelse, der studentene etter endte studier skal kunne «vurdere og bruke ulike undervisningsmetodar i skriveopplæringa og skriftforming frå 1. til 7. trinn [...]» (sitat 23). Vi spør etter studentens erfaringer med dette i praksisperioden, og peker indirekte på at vi anser metodekunnskap og -ferdigheter som en integrert del av grunnskolelærerstudiet, der begge læringsarenaer bidrar til en helhetlig utdanning.

De fleste svarene er positive, og studentene nevner relevante og lærerike erfaringer med metodisk utprøving fra praksisperioden: «Jeg har fått prøve metoder som dialog om bokstavlyder, nettbaserte oppgaver i plenum, egenarbeid, felles gjennomgang av utforming av bokstavene. I tillegg har vi snakket om hva som kreves både av lærer og elever ved utførelsen av de ulike metodene» (sitat 24). Svar som dette er uttrykk for at studentene selv ser hvordan teoretiske faglige innfallsvinkler og praktiske erfaringer kan inngå i en helhet og medvirke til å oppfylle ett og samme mål i emnebeskrivelsen. Men også i svarene på dette spørsmålet er det noen studenter som benytter anledningen til selv å opprette et skille mellom teori og praksis, og altså mellom de to læringsarenaene som de tydeligvis ikke oppfatter som likeverdig utfyllende i målet om å nå et samlet læringsutbytte: «Undervisningsmetoder har de ikke vært flinke å komme med når det gjelder [navn på norskemnet] - vi lærer for 
mye teori, vil heller lære om undervisningsmetoder» (sitat 25). Et svar som dette vitner om en forståelse av praksisfeltet som «noe annet» enn en læringsarena.

Gruppeintervjuene underbygger inntrykket fra spørreskjemabesvarelsene om at studentene opplever et skille mellom de to læringsarenaene. På et generelt spørsmål om hvordan de opplever sammenhengen mellom teori- og praksisdelen i utdanningen ( «I hvilken grad opplever dere at helhet og sammenheng mellom teori- og praksisstudier blir ivaretatt i utdanningsforløpet i GLU?»), formulerer flere studenter et savn som i hovedsak går i én retning: De ønsker at utdanningsinstitusjonen i større grad vektlegger metodisk opplæring: «[...] jeg savner mer det hvordan lære bort, for eksempel å lære bort en bokstav. Jeg visste ikke hvordan jeg skulle forklare hvorfor en A var en A. Jeg ante ikke hvordan jeg skulle forklare det til en elev. Hvorfor kunne ikke en A se sånn ut? Jeg aner ikke hvordan jeg skal møte de når de er i første klasse» (sitat 26). To studenter reflekterer på følgende vis om veien fra teoriundervisning til praktisk utøving når det gjelder bokstavinnlæring på første trinn:

Vi hadde jo gått gjennom den første lese- og skriveopplæringen [på campus, vår tilføyelse], så vi visste jo litt, men vi hadde jo ikke, [...] jeg hadde i hvert fall ikke satt meg nok inn i det, til å plutselig skulle stå der og vise frem en bokstav og si lyden, og få med alle sammen, da. Så det var en skikkelig utfordring. Det er noe annet å ha det teoretisk på skolen, enn å faktisk stå der og gjøre det, da.

(Sitat 27)

Jeg tror egentlig at du må faktisk bare hoppe i det og prøve deg frem. Det - man kan ikke lese seg til all kunnskap. Du må ut og prøve det også, spesielt i læreryrket. Så jeg tror egentlig at det er bare sånn man må gjøre det. Man må tørre å prøve og feile. Det er sånn du lærer. Selv om du har vært lærer i 20 år, så er du aldri, blir aldri ferdig utlært. Så du må jo bare prøve, rett og slett. Så jeg tror den kombinasjonen mellom teori og praksis, det ... Du må rett og slett prøve og feile.

(Sitat 28)

Oppsummert kan vi si at studentene tydelig selv tematiserer forholdet mellom teori og praksis, både der vi eksplisitt ber dem om å vurdere dette og der vi ikke gjør det, og at de oppfatter campus og praksisskolen som to ulike læringsarenaer. Mens mange trekker en linje fra undervisningen på undervisningsinstitusjonen og til praksisskolen, er det også flere som understreker forskjellen, og de rangerer gjerne praksiserfaringene høyere enn fagkunnskapene.

\section{Diskusjon}

\section{Norskfaglig kompetanse og den gode lærer}

Vektleggingen av lærerens ulike kompetanseområder (Stortingsmelding 11 (2008-2009) har fått en videre konkretisering i de siste regjeringers formelle utdanningskrav til den som skal arbeide som lærer. For studentene i denne 
konkrete undersøkelsen gjelder at de må ha minimum 30 studiepoeng i norsk for å undervise på barnetrinnet (et krav innført fra 1.1.2014). Hvordan forstår så disse studentene norskfagets rolle i skolen, og hva mener de kjennetegner den gode læreren?

Som funnene viser, var det stor konsensus blant studentene om norskfagets viktighet i skolen. I særlig grad utpeker nytteaspektet seg som noe studentene fester seg ved, og da fremfor alt lesing og skriving som nødvendige redskaper for å kunne bidra i samfunnet. Forbindelsen mellom den viktigheten av norskfaget som studentene enstemmig trekker frem i svaret på spørsmål III, og refleksjonene omkring den gode lærerens kompetanser i spørsmål VII, virker imidlertid tilfeldig og forholdsvis utydelig. Det er lærerens evne til å skape gode relasjoner til elevene som får den absolutt sterkeste tilslutningen blant studentene. Opparbeidelsen av det gode relasjonelle forholdet mellom lærer og elev blir stående som en overbygning for all annen aktivitet og kompetanseutvikling hos lærerstudenten. Dette er verken uventet eller problematisk i seg selv, men det er interessant at bare noen få av studentene helt eksplisitt knytter sammen faglig kompetanse og relasjonell kompetanse. Noen påpeker riktignok at gode fagkunnskaper gjør dem som lærere i stand til å sette seg inn i elevens tankemåte og/eller ståsted, slik at de kan hjelpe dem videre i deres faglige utvikling, men ingen trekker frem at selve relasjonen mellom læreren og eleven i seg selv kan styrkes gjennom lærerens fagkompetanse. I norskfaget kan en for eksempel tenke seg at kunnskaper om lese- og skriveutvikling vil gjøre lærerstudenten i stand til å gjenkjenne elevens ståsted, og gjennom dette vil kunne legge til rette for tilpasset undervisning - som så i sin tur vil styrke elevens selvtillit og relasjonen til læreren, ved at læreren har vært i stand til å møte eleven der eleven er. Faglig kompetanse og relasjonell kompetanse kan slik ses på som komplementære kompetanser. Dette kan høres selvsagt ut, og en kan også spørre seg om det kanskje er slik at studentene indirekte ser det på denne måten.

Funnene våre tyder på at relasjonell kompetanse holdes atskilt fra faglig kompetanse, og at studentene knytter relasjonell kompetanse til det rent omsorgsbaserte perspektivet, altså det følelsesmessige. Slik kan det se ut som om de mener at fagkunnskap i seg selv ikke er overordnet viktig for yrkesutøvelsen, så lenge deres personlige evner som relasjonsbyggere og deres holdninger til elevene, er gode. Resultatene av undersøkelsen vår viser at studentene mener at fagkunnskap er viktig, men vi ser altså samtidig en tydelig og gjennomgående underordning av fagkunnskap sett opp mot andre kompetanseområder. Uttrykk som «det viktigste» går igjen i flere utsagn, der fagkunnskap underordnes både lærerens relasjonskompetanse og lærerens generelle formidlingsevne. Disse funnene støttes av tidligere forskning, som for eksempel den nylig publiserte rapporten Om leererrollen (Dahl et al. 2016), der ekspertgruppa gjør rede for lignende funn fra studier som har vært gjort på lærerstudenters opplevelser av fagkunnskapens plass i utdanning og yrke 
(Damsgaard 2010, Heggen 2005, 2008, 2010, Smeby og Heggen 2012, Vågan og Heggen 2014, Østrem 2008).

Det er også interessant at funnene våre gir fagkunnskap en såpass underordnet rolle i forhold til formidlingsferdigheter. Det bidrar til å skape et inntrykk av at informantene mener at form er viktigere enn innhold. En kunne ellers hevde at gode fagkunnskaper kan være avgjørende viktig for formidlingsevne, siden faglig trygghet og faglig interesse kan åpne opp for større oppfinnsomhet når det gjelder formidlingsform.

Når studentene understreker at lærerens evne til relasjonsbygging og generell formidling er det vesentligste, indikerer dette at de mener at fagkunnskap i norskfaget er en supplementskompetanse til viktigere egenskaper, og den «gode læreren» i norskfaget står dermed frem som «den gode relasjonsbyggeren». Dette funnet sammenfaller med det Søreide (2010) beskriver som den mest gjeldende læreridentiteten i norsk grunnskole: den omsorgsfulle læreren som setter barnet i sentrum. Søreides undersøkelse av læreridentiteter kan forklare studentenes underordning av fagkunnskaper i sin forståelse av den gode (norsk)læreren, og den kan også gi en inngang til å forstå hvorfor studentene tillegger praksisarenaen større viktighet enn teoriarenaen i lærerutdanningen.

\section{Forholdet mellom teori og praksis på de to læringsarenaene}

I spørsmål IV uttrykker studentene gjennomgående at de savner en mer metodisk tilnærming til fagstoffet i undervisningen på utdanningsinstitusjonen. Disse funnene kan indirekte si oss noe om hvordan studentene vurderer ansvarsfordelingen mellom de to læringsarenaene, og også om hvordan de ser på seg selv og sin egen rolle i utdanningssituasjonen, og da særlig i relasjon til faglærere og praksislærere. Nilssen og Klemps (2014) omtale av praksissituasjoner som situasjoner der studenter dras mellom to roller, som lerere og lcerende, kan bidra til en relevant fortolkning av disse funnene. Undersøkelsen viser tydelig at studentene ikke ikler seg rollen som lærende på samme måte på praksisarenaen som på teoriarenaen - de går inn i «lærerrollen» på praksisarenaen, mens de på teoriarenaen ser på seg selv som studenter (Nilssen \& Klemp 2014). På den måten kan en si at de vurderer de to læringsarenaene som asymmetriske: Funnene våre kan tyde på at lærerstudentene forventer at teoriarenaen skal gjøre dem klare for alle de ulike utfordringene som møter dem på praksisarenaen. Særlig tydelig kommer dette til uttrykk i de mange utsagnene fra studentene som etterlyser metodikk på teoriarenaen.

Som vi har vist i resultatdelen, tilkjennegir studentene en forventning om å stille bedre metodisk forberedt i praksisperiodene sine, og de er tydelige på at de legger dette ansvaret på teoriarenaen. Verdien av teoretisk kunnskap blir dermed målt i metodisk nytte. Studentene ønsker seg teorier som har karakter av å være metodiske redskaper (Eritsland, 2004; Laursen, 2008), og vil gjerne vise seg frem for praksislæreren, medstudenter og elever i rollen som larer. Med 
metodene klare i bagasjen ønsker de å vise at de er forberedt til for eksempel undervisning i skriveopplæring på småskoletrinnet. Studentene identifiserer seg ikke med rollen som lcerende - i alle fall ikke i samtaler og veiledningssituasjoner med faglærere fra teoriarenaen. Når de derimot kommer tilbake til studiesituasjonen på campus, trer de tilbake inn i rollen som bare lærende, også når de skal referere til og drøfte praksiserfaringer.

Materialet vårt sier ikke så mye om dette, men i forlengelse av en slik kompleks rollefortolkning kan vi kanskje også forklare at oppfølgingen fra faglæreren på praksisarenaen kan oppleves som en uønsket rolletildeling som læerende for studenten. Ved studentens utdanningsinstitusjon gjelder allerede et sett roller, der faglæreren er lærer og studenten lærende. Når en faglærer trer inn på praksisarenaen, kan dette føre til at studenten opplever å bli tildelt en rolle som ikke samsvarer med hvordan han/hun oppfatter sin egen rolle overfor praksislæreren. Dersom studenten opplever at det blir en rollekonflikt i denne situasjonen, og må velge mellom rollen som lærer og rollen som lærende, vil et interessant spørsmål være hvorfor det synes å være slik at de gir praksisarenaen (praksisskolen) forrang for teoriarenaen (lærerutdanningsinstitusjonen).

En mulig forklaring kan være at studentenes møte med yrkeslivet kan ses på som en mer eksistensiell utfordring enn eksamener og vurderinger på høyskolen (Skagen 2010). På praksisarenaen møter studentene det som skal bli deres egen profesjonsvirkelighet (Briseid \& Werner 2013). I studien vår finner vi at studentene synes undervisningen på utdanningsinstitusjonen er mangelfull og lite relevant fordi den ikke er metodisk nok. De har vanskelig for å se at fagkunnskap kan være nødvendig for den refleksjonen som skal danne selve grunnlaget for de fagdidaktiske og metodiske valgene i undervisningen i klasserommet. Briseid og Werner viser til Fryktholm (1999), som understreker at studentene oppfatter praksislærerne som bærere av erfaringer fra «den virkelige verden», og at de derfor har en nøkkelposisjon med tanke på lærerstudentenes sosialisering inn i profesjonsfellesskapet (Briseid \& Werner 2013). I forlengelsen av dette, der studentene ønsker å identifisere seg med lærerrollen og «den virkelige verden», kan det oppleves som en nødvendighet å ta avstand fra teoriarenaen og det den representerer. Dilemmaet er at dersom en ikke evner å anerkjenne ulike typer innsikter fra både teoriarenaen og praksisarenaen, står en i fare for å få det Kvernbekk (1995) har kalt «teorityranni» eller «erfaringstyranni». Raane og Heggen skriver at det «handlar om å skape ein meiningsfull samanheng gjennom integrasjon av teoretisk og praktisk kunnskap, ferdigheiter og haldningar som i sum utviklar og formar den profesjonelle identiteten, og det handlar i praksis om å kunne sjå problem vekselvis frå eit situasjonsbestemt og eit teoretisk perspektiv» (Raane \& Heggen 2014).

I metodedelen gjorde vi greie for undervisningen som ble tilbudt studentene i norskemnet i det aktuelle semesteret. Til undervisningen var det selvsagt lagt opp pensum bestående av faglitteratur som tar for seg ulike aspekter ved 
grunnleggende lese- og skriveopplæring. Pensumutvalg og undervisning var lagt opp i tråd med emnebeskrivelsen i norskfaget. Det er interessant at når vi $\mathrm{i}$ spørsmål V retter oppmerksomheten mot det mer spesifikt faglige, så opplever vi at studenter som gir uttrykk for at de har arbeidet med fagstoffet og deltatt i undervisningen på utdanningsinstitusjonen, anerkjenner fagkunnskap som sitt hovedredskap for arbeidet i praksis. Disse studentene lar de mer generelle, allmennpedagogiske og/eller spesialpedagogiske utfordringene ligge når de blir bedt om å svare på hvordan teoretisk kunnskap om grunnleggende lese- og skriveopplæring kan være til hjelp for dem i praktisk undervisningsarbeid. Studentene har tilegnet seg fagstoff, og de har klart å omsette det til fagdidaktisk og metodisk arbeid i klasserommet, som i neste omgang kan vurderes og settes inn i en fagteoretisk kontekst. En uttalelse som den i sitat 14, viser relevant bruk av fagterminologi, og ikke minst at studenten er i stand til å utnytte teorikunnskapen i møte med konkrete praksiserfaringer. Som vi har vært inne på i resultatdelen og diskusjonsdelen, ser vi derimot at studenter som gir uttrykk for at de ikke opplever det faglige som interessant eller relevant, retter sterkere skyts mot teoripensum og fagkunnskap ved å flytte fokuset og peke på mangler de mener å finne (se sitat 17).

I spørsmålet om hvordan helheten og sammenhengen i utdanningen ivaretas gjennom norskfaget i lærerutdanningen, der teori- og praksisstudier skal være likeverdige deler (VI), ser vi tydeligst hvordan studentene selv oppretter og nærmest insisterer på et skille mellom utdanningens to læringsarenaer. Der vi selv i spørsmålsformuleringen, med et sitat fra rammeplanen, forsøker å peke på lærerutdanningen som en samlet helhet, og å koble sammen teori og praksis, holder studentene dem fra hverandre og setter dem opp mot hverandre på en måte som kan oppfattes som uproduktiv: Den ene arenaen beskyldes for ikke å ta tilstrekkelig hånd om det den andre arenaen er tenkt å ha et hovedansvar for, og det er, med et par enkeltunntak, utelukkende teoriarenaen som får unngjelde: Studentene vil ha den metodiske og utøvende delen av faget integrert i studiene ved utdanningsinstitusjonen. De etterspør imidlertid ikke i samme grad praksisarenaens ivaretakelse av teoretisk fagkunnskap. Dette er et interessant utgangspunkt for å diskutere studentenes opplevelse av (manglende) koherens og helhet i utdanningen. I en nyere artikkel fremhever Britt Oda Fosse (2016) det som viktig å hjelpe studentene til å transformere kunnskap mellom de to læringsarenaene. Fosse hevder at lærerstudentene får lite hjelp i denne prosessen.

Sitatene fra de to studentene som snakker om veien fra teoretisk undervisning i grunnleggende lese- og skriveopplæring på utdanningsinstitusjonen og til bare «å hoppe i det» i praksis, kan tjene som innfallsvinkel (sitat 27 og 28). Dette er informanter som ellers i intervjuet gir inntrykk av å delta aktivt i undervisningen, være faglig interesserte og oppdaterte og samtidig ha en klar profesjonsidentitet der de ser på seg selv som fremtidige grunnskolelærere på barnetrinnet. I de samme sitatene fremkommer 
et syn på utdanningsinstitusjonens formidling av fagkunnskap som en viktig men ikke tilstrekkelig - komponent for deres fremtidige lærergjerning. Transformasjonen av fagkunnskap til anvendt metodikk er det de selv som må stå for. De stiller ingen krav til, og retter heller ingen kritikk mot, verken teorieller praksisarenaen for manglende metodisk opplæring i de to utsagnene, men beskriver veien fra teori til praksis ved hjelp av uttrykkene «du må faktisk bare hoppe i det og prøve deg fram» og «tørre å prøve og feile». I den relativt trygge intervjusituasjonen på utdanningsinstitusjonen, der informantene har en klar rolle som studenter, beskriver disse studentene også seg selv som lcerende i praksisperioden (jf. Nilssen \& Klemp 2014).

\section{Konklusjon og implikasjoner}

Er det problematisk at studentene oppfatter at det er en «manglende sammenheng» mellom teoriarenaen og praksisarenaen? Og, ikke minst, er det mulig og ønskelig å tette et eventuelt gap? Kvernbekk (2011) har argumentert for at det ikke nødvendigvis er problematisk at det er et gap mellom teori og praksis i lærerutdanningene. Undervisningen på teoriarenaen kan bidra til å gi studentene begreper som utvikler deres pedagogiske skjønn, og deres ideer til en alternativ praksis. Det er ut fra et slikt syn et paradoks at lærerstudenter, og ofte også lærere og praksislærere, har en tendens til å si at de ikke har lært noe av teori, teorien er abstrakt og fungerer ikke i praksis. De ønsker å lære teorier som i større grad er nyttige og har karakter av redskap (Eritsland, 2004; Laursen, 2008). Men en teorinær undervisning er ikke nødvendigvis ment å skulle gi direkte oppskrifter på god lærergjerning. Gjennom undervisningen på praksisfeltet kan studentene få del i erfarne læreres erfaringer og overveielser og hjelp til å mestre konkrete situasjoner. «Limet» er noe den enkelte lærer selv må påføre. Det er ikke ønskelig med verken teorityranni (der teori dikterer praksis) eller erfaringstyranni (der erfaringen er selvtilstrekkelig) (Kvernbekk 1995).

Teoriarenaen og praksisarenaen har et likeverdig ansvar for opplæringen i grunnskolelærerutdanningene. Men undersøkelsen vår viser at dette fremdeles nok kan sies å være mer et ideal enn en realitet. Studentene klarer ikke alltid å se de to læringsarenaene som likeverdige, med et likeverdig ansvar for å klargjøre dem for arbeid i skolen. Mange gir uttrykk for at de først og fremst anerkjenner den mer praktisk orienterte kunnskapen som praksisarenaen kan gi dem gjennom direkte deltakelse i undervisningssituasjoner, og mange evner ikke å se viktigheten av å omsette den faglige kunnskapen fra teoriarenaen i konkrete undervisningssituasjoner (jf. Fosse 2016). Våre funn støtter opp om viktigheten av å hjelpe studentene til å se denne transformasjonsprosessen, men vi har også sett et skille i studentenes utsagn: De studentene i intervjuer selv oppgir at de har deltatt aktivt i undervisning på campus, gir uttrykk for at de har fått hjelp til å se hvordan fagkunnskap fra campus kan omsettes til god undervisning i praksis i 
skolen. Studenter som derimot er åpne om at de ikke har deltatt aktivt i undervisning på campus, klarer ikke selv å gjøre de nødvendige koblingene mellom fagkunnskap på de to arenaene. Hjelpen studentene trenger, må nødvendigvis komme fra begge læringsarenaene for at de skal fremstå som likeverdige, og studentene må også selv anerkjenne nødvendigheten av aktiv deltakelse på begge arenaene.

De nasjonale retningslinjene for grunnskoleopplæringen forutsetter lærere som har et helhetlig perspektiv på sammenhengen mellom teori og praksis. Som vist til tidligere, er dette krav som opprettholdes i de nye rammeplanene for femårige grunnskolelærerutdanninger. Et slikt helhetlig perspektiv kreves altså både av praksisfeltet, representert ved praksislærerne, og av teorifeltet, representert ved faglærerne ved høgskolen eller universitetet. Anerkjennelse, respekt og samarbeid mellom lærerutdannerne på de to lærerutdanningsarenaene, er dermed helt sentralt. Det at arenaene er ulike, er en styrke - ikke en svakhet: Hvis teorien kan oss å beskrive hva og hvorfor noe skjer i praksisfeltet, kan gapet mellom teori og praksis bli et rom der refleksjon kan skje (Nilssen \& Klemp 2014).

Det er interessant å merke seg at den kompetansen som praksislæreren og praksisfeltet representerer, ikke stilles samme krav til som studiene på campus. Studentene gir rett og slett ikke inntrykk av å ha reflektert over praksisskolen som en egen læringsarena med et eget kunnskapsfelt, og de etterlyser ikke praksislærerens kompetanse eller innspill, som kunne gitt dem større metodebevissthet og -refleksjon. Samtidig er studentene veldig tydelige på at de krever at faglærerne på utdanningsinstitusjonen skal vise dem direkte hvorfor og på hvilken måte fagkunnskapen er direkte relevant og nødvendig for undervisningspraksisen i skolen. Det kan virke som om tanken om et skille mellom de to læringsarenaene er en forståelse som er så nedfelt hos studentene at de ubevisst reproduserer og opprettholder det, på tross av vår intensjon som lærerutdannere om å bryte ned skillet og knytte de to arenaene sammen. En åpenbar konklusjon på dette er at det bør stilles mye tydeligere krav til lærerutdannere på begge læringsarenaene om å aktivt bidra til å hjelpe studentene til å se det som skaper sammenheng. På teoriarenaen handler det om å tydeliggjøre praksis i teori, og på praksisarenaen handler det om å tydeliggjøre teori i praksis.

Resultatene i vår studie viser at det er vanskelig for studentene, men etter vår mening helt essensielt, å skille skolefagene fra hverandre og se sammenhengen mellom teorikunnskap og didaktikk i det enkelte undervisningsfaget. De ulike skolefagenes egenart krever ulike didaktiske tilnærminger, men resultatene fra undersøkelsen vår viser at studentene ikke klarer å gripe fatt i og gjenkjenne de fagdidaktiske perspektivene i norskfaget, som vi her har fokusert på.

I både spørreskjemasvar og intervjuer kommer det frem at studentene ofte ser på didaktikk som det samme som allmenndidaktikk. Istedenfor å snakke om den fagspesifikke didaktikken, snakker de om didaktikk generelt. Videre ser de på 
allmenndidaktikk som metodikk. I de fleste utsagn som handler om elevenes læring, knytter studentene dette opp til et behov for konkret metodikk, og ikke til andre sider ved læringen og læringssituasjonen. Med dette som utgangspunkt for identitetskonstruksjonen som lærer (jf. Søreide 2010), sier det seg nesten selv at studentene ser et tydelig gap mellom de to læringsarenaene. Det er en utfordring å få begge læringsarenaene i lærerutdanningen til å tydeliggjøre og verdsette fagkunnskapens plass og relevans i studentenes utdanning, slik at faglig kompetanse kan inngå som like sentral for lærerrollen som relasjonell kompetanse. Selv om vår empiri er hentet fra kun én lærerutdanningsinstitusjon, kan resultatene bidra til den generelle diskusjonen om hva som skal til for at lærerutdanningen kan fremstå som helhetlig for studentene. Det er fremdeles en vei å gå for å oppfylle overordnede målsettinger $\mathrm{i}$ de sentrale styringsdokumentene som gjelder for grunnskolelærerutdanningene.

\section{Referanser}

Brinkmann, S. og Tanggaard, L. (2010). Kvalitative metoder - en grundbog. København: Hans Reitzels Forlag.

Briseid, L. G. \& Werner, S. (2013). Sammenheng mellom teori og praksis i lærerutdanningen? Praksislereres forståelse av og fortellinger om betydningen av tre intervensjoner for studenters utdanning til lcereryrket. Skriftserien nr. 163. Kristiansand: Universitetet i Agder.

Dahl, T. Askling, B., Heggen, K., Kulbrandstad, L. I., Lauvdal, T., Qvortrup, L., ... Thue, F. W. (2016). Om lererrollen. Et kunnskapsgrunnlag. Oslo: Fagbokforlaget.

Damsgaard, Hilde L. 2010. Den profesjonelle lærer. Oslo: Cappelen Akademisk forlag.

Eritsland, A. G. (2004). Kunnskapsstatus med vekt på allmenn- og førskolelærarutdanning. I: Norges forskningsråd (red.): Kunnskapsstatus for forskningsprogrammet KUPP. Kunnskapsutvikling i profesjonsutdanning og profesjonsutøving. Oslo: Norges forskningsråd, s. 10-28.

Fosse, B. O. (2016). Transformering av kunnskap mellom campus og skole i lærerutdanningen. Acta Didactica Norge, 10 (2), 235-251.

Fryktholm, J.A. (1999). The impact of Reform: Challenges for mathematics teacher preparation. Journal of Mathematics Teacher Education, 2 (1), 79-105.

Haug, P. (red.). (2010). Kvalifisering til læeraryrket. Oslo: Abstrakt Forlag.

Heggen, K. (2005). «Fagkunnskapens plass i den profesjonelle identiteten». Norsk Pedagogisk Tidsskrift 89, (6): 446-460.

Heggen, K. (2008). «Social workers, teachers and nurses - from college to professional work». Journal of Education and Work 21, (3), 217-231.

Heggen, K. (2010). Kvalifisering for profesjonsutøving. Sjukepleiar, læerar, sosialarbeidar. Oslo: Abstrakt forlag.

KD (Kunnskapsdepartementet). (2009). St.meld. 11 (2008-2009). Lcreren. Rollen og utdanningen. Oslo: Kunnskapsdepartementet.

KD (Kunnskapsdepartementet). (2010a). Forskrift om rammeplan for grunnskolelcererutdanningene for 1.-7. trinn og 5.-10. trinn. Fastsatt av Kunnskapsdepartementet 1 . mars 2010 med hjemmel i lov om universiteter og høyskoler av 1. april $2005 \mathrm{nr} .15$ § 3-2 nr. 2.

KD (Kunnskapsdepartementet). (2010b). Nasjonale retningslinjer for grunnskolelererutdanningen 1. -7. trinn. Oslo: Kunnskapsdepartementet. Hentet 
14.09.2016:

https://www.regjeringen.no/globalassets/upload/kd/rundskriv/2010/retningslinjer_grunnsk olelaererutdanningen_1_7 trinn.pdf

KD (Kunnskapsdepartementet). (2010c). Nasjonale retningslinjer for grunnskolelcererutdanningen 5. -10. trinn. Oslo: Kunnskapsdepartementet. Hentet 14.09.2016:

https://www.regjeringen.no/globalassets/upload/kd/rundskriv/2010/retningslinjer_grunnsk olelaererutdanningen_5_10_trinn.pdf

KD (Kunnskapsdepartementet). (2016a). Forskrift om rammeplan for grunnskolelcererutdanning for trinn 1-7. Hentet 15.09.2016: https://lovdata.no/dokument/SF/forskrift/2016-06-07-860

KD (Kunnskapsdepartementet). (2016b). Forskrift om rammeplan for grunnskolelcererutdanning for trinn 5-10. Hentet 15.09.2016: https://lovdata.no/dokument/SF/forskrift/2016-06-07-861

Kvernbekk, T. (1995). Erfaringstyranni eller teorityranni - et filosofisk perspektiv på praksis. I: Midtgård, B. (red.): Profesjonsutdanning og forskning. FoU-perspektiver på praksisfeltet. Oslo: Lærerutdanningsrådet, s. 17-27.

Kvernbekk, T. (2001). Erfaring, praksis og teori. I: Kvernbekk, T. (red.): Pedagogikk og larerprofesjonalitet. Oslo: Gyldendal Akademisk, s. 146-163.

Kvernbekk, T. (2011). Filosofisk om teori og praksis. Utdanning, 2, 20-25.

Laursen, P. F. (2008). Student teachers' conceptions of theory and practice in teacher education. I: Kentel, J. A. og Short, A. (red.): Totems and taboos: risk and relevance in research on teachers and teaching. Rotterdam: Sense Publishers, s. 171-182.

Nilssen, V. \& Klemp, T. (2014). Lererstudenten i møtet mellom teori og praksis. Oslo: Universitetsforlaget.

Raane, F. D. \& Heggen, K. (2014). Koherens i lærarutdanninga. Norsk Pedagogisk Tidsskrift 98 (1), 3 - 13. https://oda.hio.no/jspui/bitstream/10642/1959/1/1109912.pdf

Skagen, K. (2010) Teori og praksisopplæring i lærerkvalifisering. I Haug, P.(red.)

Kvalifisering til lceraryrket. Oslo: Abstrakt, s. 118-139.Smeby, J. C. og Heggen, K. (2012).

«Coherence and the development of professional knowledge and skills». Journal of Education and Work 27, (1): 1-21.

Solstad, A. G. (2010). Praksisnær teori og teorinær praksis - den nødvendige relasjonen. Norsk Pedagogisk Tidsskrift, 94 (3), 203-218.

St. meld. nr. 48 (1996-1997). Om lcerarutdanning. Oslo: Kunnskapsdepartementet.

Søreide, G. E. (2010). Fortellinger om læreridentitet. Bedre Skole, 1 (10), 69-73.

Terum, L. I. \& Heggen, K. (2010). Lærarkvalifisering og lærarkompetanse. I: Haug, Peder (red.). 2010: Kvalifisering til læraryrket. Oslo: Abstrakt Forlag.

Thagaard, T. [1998] (2013). Systematikk og innlevelse: en innføring i kvalitativ metode. Bergen: Fagbokforlaget.

Unneland, A. K. (2009). Mind the gap! - Om den praktiske og teoretiske kunnskap i lærerutdanningen. Norsk pedagogisk tidsskrift, 93 (5), 316-327.

Vågan, A. og Heggen, K. (2014). «Contextualisation of learning: a comparative study of student teachers and student nurses». Journal of Education and Work 27, (6): 608-628.

Østrem, S. (2008). En umulig utdanning til et umulig yrke? Om allmennlcererutdanning og yrkesutøvelse. Forskerskolen i Livslang læring. Doktoravhandling, Roskilde Universitetscenter.

\footnotetext{
${ }^{1}$ I denne artikkelen vises det til plan- og styringsdokumenter som var gjeldende for grunnskoleopplæring og lærerutdanning på det tidspunktet undersøkelsen ble gjennomført.

${ }^{2}$ Studentsitatene fra spørreskjemaene gjengis som de er, inkludert eventuelle skrivefeil.
} 


\section{Helhetlig og bærekraftig lærerutdanning ved (utdanningsinstitusjon)}

\section{Spørreskjema, GLU 1-7, etter endt praksisperiode 3. semester}

Hvilke(t) klassetrinn har du undervist på i praksisperioden?

Hvilke emner i norskfaget har du undervist i?

Hva tenker du om norskfagets betydning i grunnskolen? Begrunn dette.

IV)I emnebeskrivelsen for (emnekode) står det at studentene etter endt studium skal kunne «vurdere og bruke ulike undervisningsmetodar i skriveopplæringa og skriftforming frå 1. til 7. trinn $(\ldots) »$

Hvilke erfaringer har du gjort deg når det gjelder dette i praksisperioden?

V)I emnebeskrivelsen for (emnekode) står det at studentene etter endt studium skal ha «kunnskap om lese- og skriveteoriar og om ulike teoriar innan lese- og skriveopplæring, med særleg vekt på begynnaropplæringa»

Har teoretisk kunnskap vært til hjelp i undervisningssituasjoner, for eksempel til

a) å forstå elevers ferdigheter og utfordringer. Vis gjerne til eksempler.

b) at du selv kan gi faglig relevant opplæring? Vis gjerne til eksempler.

VI)I «Forskrift om rammeplan for grunnskolelærerutdanningene» står det at utdanningene skal vektlegge «helhet og sammenheng mellom teori- og praksisstudier»

Dette ansvaret deles mellom praksislærere på praksisskolene og faglærerne på (utdanningsinstitusjonen). I hvilken grad opplever du at helheten og sammenhengen i sitatet ovenfor blir ivaretatt i norskfaget i GLU?

VII)Hva mener du kan gjøre deg til en god lærer? 


\section{Helhetlig og bærekraftig lærerutdanning ved (utdanningsinstitusjon)}

\section{Intervjuguide, GLU 1-7, fokusgruppeintervju etter endt praksisperiode 3. semester}

Del I: Bakgrunnsinformasjon:

Hvilke(t) klassetrinn har dere undervist på i praksisperioden?

Hvilke emner i norskfaget har dere undervist i?

Har dere tidligere undervist på andre klassetrinn og i andre emner?

Del II: Teori og praksis i utdanning og skole

I hvilken grad opplever dere at helhet og sammenheng mellom teori- og praksisstudier blir ivaretatt i utdanningsforløpet i GLU?

Hva legger dere i begrepet forskning?

Hvilken betydning mener dere at forskning har hatt i norskfaget i GLU 1-7 dette semesteret (f.eks. faglitteratur, undervisning, arbeidsmåter)?

Hva legger dere i begrepet fagdidaktikk?

Hva tenker dere om forholdet mellom fagkunnskap og din egen utvikling gjennom studiet fram mot læreryrket?

Hva tenker dere om forholdet mellom fagdidaktisk kunnskap og forberedelse fram mot yrkesutøvelse som lærer?

Opplevde dere at fagdidaktiske utfordringer oppstod underveis i praksisperioden i forbindelse med helt konkrete situasjoner? Kan dere gi eksempler?

Opplevde dere at fagkunnskap dere har tilegnet dere i norskfaget i lærerutdanningen kunne hjelpe dere i planlegging og gjennomføring av undervisning i praksisperioden? Begrunn svaret.

Opplever dere at dere selv har benyttet kjennskap til hvordan forskning kan brukes praktisk i planlegging og/eller vurdering av egen undervisning i praksisperioden?

Hvordan opplever du at forskning og fagdidaktikk har kommet til syne i norskfaget i lærerutdanningen, sammenliknet med i andre fag? Begrunn svaret.

Hva har dere opplevd som den største utfordringen i praksisperioden?

Del III: Overordnede refleksjoner

Hvis dere skulle foreslå noe som kunne gjøre lærerutdanningen bedre, hva ville det være?

Hvis dere skulle foreslå noe som gikk konkret på sammenhengen mellom teori og praksis i fagene, hva ville det være?

Hvordan er den perfekte lærer? 